\title{
What are children learning in early childhood education in New Zealand?
}

\author{
Ken Blaiklock \\ Unitec Institute of Technology
}

IT IS WIDELY ASSUMED that children's learning is enhanced through being involved in early childhood education but the evidence to substantiate this in New Zealand is limited. Sources of information that could be expected to show what children are learning include the national curriculum, documentation provided by early childhood centres, evaluations from the Education Review Office, and government-funded research reports. This article examines each of these sources and finds they provide little evidence about what children are learning. One of the difficulties is the strong reliance on Learning Stories as the main form of assessment in centres and research investigations. A case is made that it is time for the Ministry of Education to reconsider the advice it is providing on how to assess young children's learning.

\section{Introduction}

Early childhood education has undergone a period of considerable growth and change in New Zealand over the past 20 years. The changes have included the introduction of the national curriculum, Te Whäriki (Ministry of Education, 1996), and the implementation of a strategic plan, Pathways to the Future (Ministry of Education, 2002). The strategic plan set out policy and funding changes aimed at increasing the quality of early childhood services and participation rates, especially for children of Maori and Pasifika descent and those from low socioeconomic communities. Government funding for children in ECE has increased significantly and is now more than \$NZ 9000 per child (full-time equivalent), higher than funding for primary and secondary school students (Ministry of Education, 2011a, 2012).

Given the many changes and the large amounts of funding now directed at the sector, it is timely to consider what information is available about the effectiveness of early childhood education in New Zealand. A crucial area to consider, and a legitimate question to ask is: What are children learning through their experiences in early childhood services? Although the early childhood years are a time of rapid growth in all areas of development, finding evidence about what young children are learning, and whether that learning is at least partly attributable to early childhood education, is a complex task.

Information about what children may be learning in early childhood education is available from a range of sources. The national curriculum, Te Whāriki (Ministry of Education, 1996), outlines important areas of learning for teachers to consider. Relevant information is also available in the assessment documentation produced by teachers in early childhood centres and in reports made by the Education Review Office. Another source of information is the early childhood research projects that have been funded by the Ministry of Education over the past 10 years. The following discussion will examine each of these sources of information in order to evaluate the evidence that is currently available about children's learning in early childhood settings in New Zealand.

\section{Te Whäriki, the early childhood curriculum}

Te Whāriki, the New Zealand early childhood curriculum, has been widely praised since it was introduced in 1996. Praise has been given for its connections with sociocultural theory and for its holistic, non-prescriptive approach (Ritchie \& Buzzelli, 2011; Smith, 2003, 2011). Fleer (2003) commented that Te Whäriki has had an enormous impact on curriculum development in many countries, including Australia (p. 243) and 'has gained international prominence as an early childhood curriculum of great substance and importance' (p. 244). Cullen (1996) noted that teachers embraced the curriculum with great enthusiasm, 'to the extent that it has taken on a gospel like status' (p. 123). The enthusiastic support of teachers for the curriculum was also seen in interviews conducted by Alvestad and Duncan (2006). 
Recently, Te Whāriki received a strong endorsement in the report of the Early Childhood Education Taskforce (ECE Taskforce, 2011). The taskforce was set up by the New Zealand Government to review the effectiveness of funding for the early childhood sector. Among its findings, the taskforce reported that, 'Te Whäriki is considered a model of best practice, nationally and internationally' (p. 106). The taskforce did note there was a need for 'a comprehensive review of its implementation' (p. 106), but made no criticism of the structure or content of Te Whäriki.

What then does Te Whāriki tell us about what children are learning in early childhood education in New Zealand? Te Whāriki emphasises that children's learning is integrated and holistic and occurs within sociocultural settings. Areas of learning are described within the five overlapping strands of Te Whāriki (Ministry of Education, 1996, pp. 15-16):

1. Wellbeing

The health and wellbeing of the child are protected and nurtured.

\section{Belonging}

Children and their families feel a sense of belonging.

3. Contribution

Opportunities for learning are equitable, and each child's contribution is valued.

4. Communication

The language and symbols of their own and other cultures are promoted and protected.

\section{Exploration}

The child learns through active exploration of the environment.

Each strand is subdivided into three or four goals that are further subdivided into a number of learning outcomes. The learning outcomes, however, are often phrased in very general terms because they have usually been designed to be broad enough for any child, regardless of age or developmental level. The lack of recognition of developmental change in the birth to five-year age range severely limits the usefulness of the learning outcomes for providing information about what children may be learning at particular phases in the early childhood years.

Another limitation on the value of the learning outcomes in Te Whäriki is that they are 'indicative rather than definitive. Each early childhood setting will develop its own emphases and priorities' (Ministry of Education, 1996, p. 44). There is no requirement for early childhood centres to ensure that any particular learning outcomes are included in their programs. The lack of guidance in Te Whāriki means that it would be quite possible for a centre to believe it is offering a comprehensive program when it may in fact be neglecting crucial areas of learning (see Blaiklock, 2010a).

\section{Assessment of children in early childhood centres}

Just as there is no requirement for centres to focus on particular learning outcomes, so there is no requirement to assess particular areas of children's learning. The regulations for early childhood services (Ministry of Education, 2009) state that services should be 'informed by assessment, planning, and evaluation (documented and undocumented) that demonstrates an understanding of children's learning, their interests, whanau [family] and life contexts' (p. 8). There are no requirements to document any specific areas of learning and development; it is up to individual centres and teachers to decide what to assess.

Somewhat surprisingly, given the lack of guidance on what to assess, the Ministry of Education has directed large amounts of funding at telling teachers how to assess. Internationally recognised methods of assessment (see e.g. Bagnato, 2007; Wortham, 2012) have fallen out of favour to make way for the locally developed technique of Learning Stories (Carr, 1998a; 2001; Carr \& Lee, 2012).

Learning Stories are narrative descriptions that teachers write to describe and interpret the learning that occurs in particular situations. They were designed to focus on children's dispositions to learn rather than highlighting knowledge and skills. A major difficulty with Learning Stories, however, is that the dispositions they are supposed to assess have not been clearly defined. Carr (2001) described learning dispositions as 'situated learning strategies plus motivation-participation repertoires from which a learner recognises, selects, edits, responds to, resists, searches for and constructs learning opportunities' (p. 21). It remains unclear as to how such constructs are manifested for different children in different contexts. Carr (1998b) suggested that certain behaviours can be taken as indicators of particular dispositions which in turn can be linked to particular strands of Te Whāriki. For example, the behaviour of 'being involved' is said to be indicative of the disposition of 'trust and playfulness' which relates to the curriculum strand of 'wellbeing'. The rationale for linking particular behaviours to particular dispositions and strands is unclear. Nor has Carr described how behaviours and dispositions may change as children learn and develop from birth to age five years.

The topic of children's learning dispositions is of considerable interest to educators and it is to be hoped that further research in this area will be of value. Currently, however, the lack of clarity and understanding about dispositions means that attempts to assess them are highly problematic. Furthermore, a legitimate concern about the emphasis on assessing dispositions is that it could lead to important areas of knowledge 
and skill development being overlooked. Other concerns about Learning Stories include the lack of evidence on validity or credibility, questions about their usefulness for planning, and problems in trying to use Learning Stories to show changes in children's learning over time (see Blaiklock, 2008; Nuttall, 2005).

Although the effectiveness of Learning Stories has not been established, this method of assessment has become the main form of assessment in most centres in New Zealand. A national survey in 2007 found that 94 per cent of centres were using Learning Stories as the main method of assessment (Mitchell, 2008). The rise in the use of Learning Stories can be linked to substantial government funding for teacher professional development contracts that promote this approach. There has also been considerable expenditure on developing and distributing Kei Tua o te Pae: Early Childhood Exemplars, a series of 20 resource booklets that focus on the use of Learning Stories (Ministry of Education, 2004, $2007,2009)$. Each of the booklets focuses on a theme (e.g. bicultural assessment, community), a particular strand of Te Whäriki, or a curriculum subject area such as mathematics or art. The booklets provide examples of how teachers have attempted to use Learning Stories to make evaluations of children's dispositions and learning in particular experiences. Although there are examples of children developing knowledge and skills in curriculum or discipline areas, these are presented in an eclectic fashion that provide teachers with little guidance on how to assess changes in children's learning in crucial areas such as physical development, social relationships, and language development (see Blaiklock, 2010b).

The dominance of Learning Stories as a method of assessment in New Zealand has resulted in a situation where centres may be unable to provide valid evidence about how children are progressing in key aspects of learning. The use of an unproven assessment method, coupled with a lack of guidance from the Ministry of Education on what or when to assess, raises important concerns about the worth of assessment information collected in centres. In summary, current assessment procedures are of limited value for showing what children are learning, let alone for showing that the learning is, at least in part, the result of being involved in early childhood education.

\section{Education Review Office reports}

The Education Review Office (ERO) is the government department that undertakes regular evaluations of all early childhood centres in New Zealand. ERO has a crucial role in ensuring that children are provided with high-quality care and education. Centres are reviewed every three years according to criteria related to management, teaching practices, children's learning and assessment procedures.
A feature of ERO is that it is independent from the Ministry of Education. The autonomy of ERO enables it to comment on practices that could limit the quality of care and education, even if the practices are supported by the Ministry of Education. With regard to assessment, the independence of ERO could allow it to act as a check on the current emphasis by the Ministry of Education on the almost exclusive use of Learning Stories as a means of assessing children's learning in early childhood centres.

ERO, however, has provided no cautions on the use of Learning Stories, despite the lack of empirical evidence that this assessment approach is an effective way of assessing and enhancing children's learning. Rather than raising concerns, ERO has actively supported the use of Learning Stories in its comments when reporting on individual centres and in the findings of a national report undertaken by $E R O$ on the quality of assessment in early childhood education (ERO, 2007).

ERO's mission statement declares that the role of ERO is 'to provide high quality evaluation that contributes to high quality education for all young New Zealanders' (ERO, 2011, p. 3). However, a 'high quality evaluation' of a centre should surely include an evaluation of how the centre program contributes to children's learning. The difficulty ERO faces is that it must rely on assessment documentation collected by a centre. Such documentation usually consists of collections of Learning Stories and may provide little evidence about children's learning in important areas. There is no requirement for centres to assess crucial aspects of children's learning (e.g. physical skills, language development, mathematical concept knowledge, social development).

ERO's reliance on Learning Stories as the main source of assessment information may explain the very general nature of the comments that ERO makes about children's learning when reviewing a centre. ERO reports on individual centres nearly all comment on learning in the generic sense with no reference to a particular area or type of learning. Typical comments in ERO reports refer to 'the learning environment', 'extending children's learning' and 'good quality teaching and learning experiences'. What it is that children may be learning is not specified. The lack of specificity means that ERO cannot indicate whether children's learning is the result of experiences in a centre rather than being the result of general development and home experiences. The lack of detail also means that ERO cannot note if there are differences between children in levels of learning in particular areas (e.g. early literacy knowledge). In turn, this means that ERO cannot examine how programs address such educational disparities. 


\section{Ministry of Education-funded research projects}

Since 2003, the Ministry of Education has supported research into early childhood education through two major funding sources: the Centres of Innovation (COI) program and the Teaching and Learning Research Initiative (TLRI). Twenty COI projects were supported with total funding of approximately \$NZ 5 million. Eighteen early childhood TLRI projects have been undertaken at a cost of nearly \$NZ 3 million.

The intention of the Centres of Innovation program was to foster research into innovative teaching and learning processes occurring in particular early childhood centres. Staff at these centres worked with experienced researchers in using action research techniques to investigate areas of teaching and learning. The results of the projects were made available through reports, conference presentations, and five booklets (Meade, 2005, 2006, 2007, 2009, 2010a).

The COI program has been valuable for providing descriptions of some centre initiatives which may be of interest to others in the early childhood sector. Participants in COI projects have reported that there have been benefits for teachers in providing opportunities to more closely examine innovative teaching practices. What is missing, however, from all of the COI projects is valid information about whether the teaching practices were effective in enhancing children's learning.

The lack of information on the effects on learning was noted in a report commissioned by the Ministry of Education to evaluate the COI program. Gibbs and Poskitt (2009) concluded that it 'appeared teachers knew little about the impact of their initiatives on children as a whole because they had not established processes for gathering and analysing centre-wide data' (p. 9). Often the only information collected on children's learning was with the use of Learning Stories. Centre teachers were only able to provide general comments about the impact on the children as a whole group in a centre. The teachers believed that their practice had improved and that this would result in benefits for children's learning. However, they were unable to provide evidence that changes in practice were linked to changes in learning (see also Meade, 2010b).

Similar concerns about a lack of evidence on children's learning have been expressed in relation to early years projects in the TLRI program. Nuttall (2010) commented that 'most of the projects have a strong emphasis on how children learn in the early years, and how teachers can foster and track this development; it is less clear what the children in these projects were learning, other than a particular set of orientations to learning itself' $(p$. 9). Nuttall suggested that the emphasis on orientation to learning is a consequence of a reliance of many of the projects on Carr's work on learning dispositions (e.g. Carr, 1998a, 2001). The difficulty with relying on this work is that, as Carr et al. (2008) themselves acknowledge, 'learning dispositions and key competencies are fuzzy concepts and although they are about observable action they are represented by language. Dispositional language is imprecise, situated, personalised and value laden ...' (p. 87, as cited in Nuttall, 2010, p. 9).

Nuttall (2010) argued that 'this fuzziness, in combination with a lack of explicit engagement with the sociocultural theoretical principles assumed by most of the projects, gives the projects completed so far a somewhat ephemeral quality in terms of the knowledge outcomes produced' (p. 9). Nuttall acknowledged the projects have strengths, particularly in relation to knowledge of practice in specific local settings. Nevertheless, the comments about the lack of information on what children were learning raises serious concerns about the worth of much of the early years research funded through the TLRI program.

\section{Conclusion}

This article sought to answer the question: What are children learning in early childhood education in New Zealand? The answer would appear to be that we don't know. Sources of information ranging from Te Whäriki through to centre documentation, ERO evaluations and Ministry of Education-funded research projects all fall short in providing evidence about what children are learning, let alone showing that early childhood education is contributing to that learning.

International evidence, using a broad range of valid and reliable assessments, shows that early childhood education can make an impact on children's learning, particularly for those from disadvantaged backgrounds (Burger, 2010; OECD, 2006). The evidence also shows that the effectiveness of early childhood education is dependent of the quality of the program (OECD, 2011; Sylva \& Roberts, 2010). The current lack of information in New Zealand about what children are learning makes it difficult to evaluate the quality of programs being provided by early childhood centres in this country.

Given the large amounts of government funding allocated to early childhood education in New Zealand (approximately \$NZ 1.35 billion each year [Ministry of Education, 2011b]) and the commitment of many talented teachers, it is hoped that children are benefiting from their experiences in early childhood centres. However, we need to move beyond hopes and instead provide evidence that shows what children are learning through their participation in early childhood programs. Making use of assessment techniques that are widely used internationally would provide such evidence (see e.g. Bagnato, 2007; National Research Council, 2008). 
The use of valid assessment procedures would also allow teachers to monitor the effectiveness of their work and to adjust their programs in response to the individual needs of children. This could help to reduce the disparities in learning that are found at school entry which, in turn, contribute to increased inequities in educational outcomes during the school years. For all of these reasons, it is time for the Ministry of Education to reconsider the advice it has been providing on how to assess children's learning in early childhood education in New Zealand.

\section{References}

Alvestad, M., \& Duncan, J. (2006). 'The value is enormous - It's priceless I think' New Zealand preschool teachers' understanding of the early childhood curriculum in New Zealand: A comparative perspective. International Journal of Early Childhood, 38(1), 31-45.

Bagnato, S. J. (2007). Authentic assessment for early childhood intervention: Best practices. New York: Guildford Press.

Blaiklock, K. (2008). A critique of the use of learning stories to assess the learning dispositions of young children. New Zealand Research in Early Childhood Education, 11, 77-87.

Blaiklock, K. (2010a). Te Whäriki, the New Zealand early childhood curriculum: Is it effective? International Journal of Early Years Education, 18(3), 201-212.

Blaiklock, K. (2010b). The assessment of children's language in New Zealand early childhood centres. New Zealand Journal of Educational Studies, 45(1), 105-110.

Burger, K. (2010). How does early childhood care and education affect cognitive development? An international review of the effects of early interventions for children from different social backgrounds. Early Childhood Research Quarterly, 25(2), 140-165.

Carr, M. (1998a). Assessing children's learning in early childhood settings: A professional development programme for discussion and reflection. Wellington: New Zealand Council for Educational Research.

Carr, M. (1998b). Assessing children's experience in early childhood: Final report to the Ministry of Education. Wellington, New Zealand: Ministry of Education.

Carr, M. (2001). Assessment in early childhood settings: Learning stories. London: Paul Chapman.

Carr, M., \& Lee, W. (2012). Learning stories: Constructing learner identities in early education. London: Sage.

Cullen, J. (1996). The challenge of Te Whāriki for future developments in early childhood education. Delta, 48(1), 113-126.

ECE Taskforce. (2011). An agenda for amazing children: Final report of the ECE Taskforce. Wellington: Ministry of Education.

ERO (Education Review Office). (2007). The quality of assessment in early childhood education. Wellington: Education Review Office.

ERO (Education Review Office). (2011). Annual report. Wellington: New Zealand Government.

Fleer, M. (2003). The many voices of Te Whāriki: Kaupapa Maori, Socio-cultural, developmental, constructivist, and ...? Australians listen carefully. In J. Nuttall (Ed), Weaving Te Whäriki: Aotearoa New Zealand's early childhood curriculum document in theory and practice (pp. 243-268). Wellington: New Zealand Council for Educational Research.
Gibbs, R., \& Poskitt, J. (2009). Report on the evaluation of the early childhood Centres of Innovation programme. Auckland: Evaluation Associates Ltd.

Meade, A. (Ed). (2005). Catching the waves: Innovation in early childhood education. Wellington: New Zealand Council for Educational Research.

Meade, A. (Ed). (2006). Riding the waves: Innovation in early childhood education. Wellington: New Zealand Council for Educational Research.

Meade, A. (Ed). (2007). Cresting the waves: Innovation in early childhood education. Wellington: New Zealand Council for Educational Research.

Meade, A. (Ed). (2009). Generating waves: Innovation in early childhood education. Wellington: New Zealand Council for Educational Research.

Meade, A. (Ed). (2010a). Dispersing waves: Innovation in early childhood education. Wellington: New Zealand Council for Educational Research.

Meade, A. (2010b). The contribution of ECE Centres of Innovation to building knowledge about teaching and learning 2003-2010. Paper presented at the TLRI Symposium, Wellington, New Zealand. Retrieved 10 December 2012, from TLRI website: http://tlri.org.nz/sites/default/files/background-paper-pdfs/ AMeade-ECE-Paper2010.pdf.

MoE (Ministry of Education). (1996). Te Whāriki: He Whāriki mo-tauranga mā ngā mokopuna o Aotearoa. Early childhood curriculum. Wellington: Learning Media.

MoE (Ministry of Education). (2002). Pathways to the future: Nga Huarahi Aratiki. A 10 year strategic plan for early childhood education. Wellington: Learning Media.

MoE (Ministry of Education). (2004, 2007, 2009). Kei tua o te pae: Assessment for learning: Early childhood exemplars. Wellington, New Zealand: Learning Media.

MoE (Ministry of Education). (2009). Licensing criteria for early childhood education and care centres 2008 and early childhood curriculum framework. Wellington: Learning Media.

MoE (Ministry of Education). (2011a). Briefing to the incoming Minister. Wellington: Ministry of Education.

MoE (Ministry of Education). (2011b). Annual report. Wellington: Ministry of Education.

MoE (Ministry of Education). (2012). Funding subsidy, Vote Education, and total government expenditure per full-time equivalent. Retrieved 10 December 2012, from www. educationcounts.govt.nz/_data/assets/excel_doc/0004/105628/ ECE-Expenditure.xls.

Mitchell, L. (2008). Assessment practices and aspects of curriculum in early childhood education. Wellington: New Zealand Council for Educational Research.

National Research Council. (2008). Early childhood assessment: Why, what, and how? Committee on developmental outcomes and assessments for young children, C. E. Snow and S. B. Van Hemel (Eds). Washington, DC: The National Academies Press.

Nuttall, J. (2005). Looking back, looking forward: Three decades of early childhood curriculum development in Aotearoa New Zealand. Curriculum Matters, 1, 12-28.

Nuttall, J. (2010). The contribution of the Teaching and Learning Research Initiative to building knowledge about teaching and learning: A review of early years projects, 2004-2010. Paper presented at the TLRI Symposium, Wellington, New Zealand. Retrieved 10 December 2012, from TLRI website: http://tlri. org.nz/sites/default/files/background-paper-pdfs/Nuttall_TLRI_ final_paper2011.pdf. 
OECD (Organisation for Economic Co-operation and Development). (2006). Starting strong II: Early childhood education and care. Paris, France: OECD Publishing.

OECD (Organisation for Economic Co-operation and Development). (2011). Starting strong III: A quality toolbox for early childhood education and care. Paris, France: OECD Publishing.

Ritchie, J., \& Buzzelli, C. A. (2011). Te Whariki: The early childhood curriculum of Aotearaoa New Zealand. In N. File, J. J Mueller \& D. B. Wisnewski (Eds), Curriculum in early childhood education: Re-examined, rediscovered, renewed (pp. 146-159). New York: Routledge.

Smith, A. (2003). What is special about early childhood education in New Zealand? International Journal of Early Years Education, 11(1), 3-6.
Smith, A. B. (2011). Relationships with people, places and things - Te Whāriki. In L. Pound \& L. Miller (Eds), Theories and approaches to learning in the early years (pp. 149-162). London: Sage.

Sylva, K., \& Roberts, K. (2010). Quality in early childhood education: Evidence for long-term effects. In G. Pugh \& B. Duffy (Eds), Contemporary issues in the early years (5th ed., pp. 47-62). London: Sage.

Wortham, S. C. (2012). Assessment in early childhood education (6th ed.). Boston, MA: Pearson. 